\title{
Formation of soil microflora in Trifolium pratense's agrocenosis depending on the method of tillage
}

\author{
Ivan Shuvar, Ivan Dudar, Olha Dudar, Hanna Korpita*, and Bogdan Shuvar \\ Lviv National Agrarian University, 80381, V. Velykoho1, Dublyany, Ukraine
}

\begin{abstract}
The biological activity of the soil was studied according to the indicators of the number of microflora on the dark gray podzolic soil of the western Forest-Steppe of Ukraine. The influence of the methods of tillage on the course of biological processes under Trifolium pratense is clarified. The relationship between the quantitative characteristics of the microbial grouping of soil agrocenosis of the culture, its biological activity and methods of tillage. It was found that the largest number of microorganisms was observed in the variants of combined tillage. Over the years of research, the highest yield of hay was obtained by the Combined tillage $(124.5 \mathrm{c} / \mathrm{ha})$, the lowest - by chisel tillage ( $106.5 \mathrm{c} / \mathrm{ha})$, which is due to changes in microbiological activity of the soil.
\end{abstract}

\section{Introduction}

Soil is the main natural environment in which the biological diversity of living organisms is formed. Negative anthropogenic impact on it leads to changes in fertility and impaired ecosystem stability [19].

An important component of effective fertility is the biological activity of the soil, which depends on the number and activity of microorganisms of different ecological and trophic groups and ensures the ecological balance of agroecosystems [9]. They provide important functions of transformation of nutrients and energy, able to complete the cycle of elements that are inaccessible to higher organisms [6]. Soil biota, on the one hand, depends on the ecological conditions of the soil, and on the other - due to its vital activity changes the ecological functions of the soil: strengthening or weakening them. The biological activity of the soil is a reflection of a complex of microbiological processes and is an important indicator of changes in agrophysical and chemical properties, indicates the conditions of nutrition, growth and development of plants [15].

The functioning of the soil microflora is an important factor in improving soil structure. Fungi and actinomycetes, which surround soil particles with mycelium and form water resistance of aggregates [29].

The number of microorganisms in the soil (indicator of soil biogenicity), as an important component of soil organic matter quantitatively and qualitatively, depending on various factors, in particular, soil type, climatic conditions, elements of agricultural

* Corresponding author: korpita@ukr.net 
technology, environmental reaction $(\mathrm{pH})$, etc. $[1,2,3,9,14,15,17,22]$. It has been found that there are fewer microorganisms in sandy and stony soils than in dark gray and chernozem, and especially fertilized soils. Some types of actinomycetes and molds give the soil color and smell. Most soil microorganisms are able to grow at neutral $\mathrm{pH}$, high relative humidity, temperature $25-45^{\circ} \mathrm{C}[12]$.

Soil biological activity is assessed by various factors: enzyme activity, rate of decomposition of organic matter, intensity of nitrification and ammonification processes, integrated indicators of abundance, biodiversity of taxonomic and physiological groups of microorganisms, intensity of carbon dioxide release in the soil-plant system [13].

A number of scientists $[3,9,15,16,17,21]$ note the influence of fertilizer system, tillage method, humidity, temperature, soil density, soil composition where the transformation takes place, humus and nutrients content, abundance, biomass and species composition of microorganisms, etc. on the biological activity of the soil. Increased aeration activates the vital processes of aerobic microorganisms. Increasing the density of the soil structure reduces the content of oxygen in the soil air and increases carbon dioxide $[3,9,15,16,17,21]$.

The use of imperfect technologies for growing crops has a negative impact on the biological activity of the soil. Therefore, the problem of enrichment and activity of soil microflora is constantly in the field of view of scientists from around the world [12, 23-27].

The quantitative composition and ratio of individual representatives in the microbial coenosis of the soil largely depends on the method of tillage [21].

Unfortunately, in the conditions of production agrotechnical measures, in particular, the influence of the method of basic tillage in the technology of growing crops is practically not assessed by the influence on the intensity and direction of microbiological processes.

\section{Material and methods}

The study of the development of the main groups of microorganisms in the agrocenosis Trifolium pratense depending on the method of basic tillage was performed during 20182020 in the western forest-steppe of Ukraine.

The experiment included three variants of the method of tillage: 1 . Conventional tillage (control) - plowing with a plow PLN-4-35; 2. Chisel tillage - plowing with the plow PCH4,$5 ; 3$. Combined tillage - plowing with the plow PYA-4-40

Agrotechnical conditions for growing Trifolium pratense were generally accepted for the western forest-steppe of Ukraine.

The soil of the experimental plot is dark gray podzolic light loam, characterized by a low content of humus (2.80-2.85\%). The reaction of the soil solution is slightly acidic (saline $\mathrm{pH}-5.7-5.8)$. The supply of soil with easily hydrolyzed nitrogen is low (106-110 $\mathrm{mg} / \mathrm{kg}$ of soil), phosphorus (188-193 mg / $\mathrm{kg}$ of soil) and potassium is medium (122-126 $\mathrm{mg} / \mathrm{kg}$ of soil).

The following horizons are highlighted in the soil profile:

He - 0-24cm - humus, well-eluted, arable, dark gray, moist, coarse-dusty-loamy, agileslightly lumpy, loose, noticeable powder $\mathrm{SiO}_{2}$.

He - 25-40 cm - humus, well-eluted, subsoil, dark gray, moist, coarse-dusty-loamy, compacted, lamellar-fine-grained, noticeable powder $\mathrm{SiO}_{2}$; the transition is gradual.

Hi - 41-72 cm - humus-illuvial, grayish-brown, coarse-dusty-loamy, compacted, nutty, and deep - prismatic, in the upper part there is a powder of $\mathrm{SiO}_{2}$; the transition is gradual.

I - 73-90 cm - illuvial, yellow-brown, coarse-dusty-loamy, prismatic, $\mathrm{SiO}_{2}$ powder occurs in the upper part; the transition is gradual.

$\mathrm{Pi}$ - 91-130 cm - illuviated rock, yellow-brown, coarse-dusty-medium loam; the transition is sharp, uneven.

$\mathrm{Pk}$ - 131-180 cm - parent rock, yellow-pale, loamy, carbonate. 
To study the peculiarities of the development of microorganisms in the soil in crop rotation agrocenoses, soil samples were taken using a cylindrical drill from arable (0-20) and subsoil (20-40) horizons with an average weight of an individual sample of $300 \mathrm{~g}$. For microbiological analysis, average samples of five individual samples were prepared.

The following groups of microorganisms were determined in the soil: bacteria on meat peptide agar, fungi on wort agar, actinomycetes on starch-ammonia medium.

\section{Results and discussion}

Improving the agrophysical and water properties of the soil under the influence of its cultivation undoubtedly affects the course of microbiological processes, and, consequently, the effective fertility.

We found that the development of microorganisms depends on the method of basic tillage (Tables 1, 2, 3, Fig. 1, 2, 3). Thus, in 2018 in the arable horizon, the maximum number of bacteria was in the Combined tillage of basic tillage - 3131.7 thousand / $\mathrm{g}$ of soil, and the smallest - 2880.7 thousand / $\mathrm{g}$ of soil under conventional tillage (control). In 2019 and 2020, the number of bacteria changed, but the patterns remained. The maximum number of bacteria was in the third version of the experiment and was 2872.3 thousand / $\mathrm{g}$ of soil and 4371.0 thousand / $g$ of soil respectively.

A similar number of bacteria was found in the subsoil horizon $(20-40 \mathrm{~cm})$, the bacterial mass ranged from 2044.7 to 2238.7 thousand (2018), from 1931.3 to 2149,0 thousand (2019) and from 2195,7 to 2591.0 thousand / g of soil(2020). The most favorable conditions for the activity of bacteria were in the variant of plowing with the plow PYA-440 , in which the number of bacteria was 395.3 thousand more compared to the control and 594 thousand more than the option of chisel tillage.

The largest number of bacteria over the years of the study was found at the beginning of the growing season - in April and June. In the variant of plowing PLN-4-35 on average during the vegetation of the culture there was a decrease in the number of bacteria compared to the variant of combined tillage.

It was found that in the variant of application of chisel tillage, the reduction of the number of bacteria compared to the control lasted during the growing season.

Table 1.The number of bacteria in the soil of the agrocenosis of Trifolium pratense, depending on the method of its tillage, thousand / $\mathrm{g}$ of soil (average for vegetation).

\begin{tabular}{|c|c|c|c|c|c|c|c|}
\hline \multirow{2}{*}{ Method of tillage } & \multicolumn{7}{|c|}{ Soil horizon, sm } \\
\cline { 2 - 7 } & $0-20$ & $20-40$ & $0-20$ & $20-40$ & $0-20$ & $20-40$ \\
\cline { 2 - 7 } & \multicolumn{2}{|c|}{2018} & \multicolumn{2}{|c|}{2019} & \multicolumn{2}{|c|}{2020} \\
\hline $\begin{array}{c}\text { Conventional } \\
\text { tillage (control) }\end{array}$ & 2880,7 & 2044,7 & 2700,7 & 1931,3 & 3178,7 & 2195,7 \\
\hline Chisel tillage & 2659,3 & 1889,3 & 2559,3 & 1712,7 & 2917,7 & 1997,0 \\
\hline Combined tillage & 3131,7 & 2238,7 & 2872,3 & 2149,0 & 4371,0 & 2591,0 \\
\hline
\end{tabular}

We found that the Combined tillage of basic tillage promotes more intensive development of bacteria compared to conventional and chisel tillage. The number of bacteria in the arable horizon in the variant of combined cultivation averaged 3458.3 thousand over the years of the study, while in the variants of chisel and conventional tillage the indicators were lower and were - 2712.1 and 2920.0 thousand / g of soil respectively. (Fig. 1). 


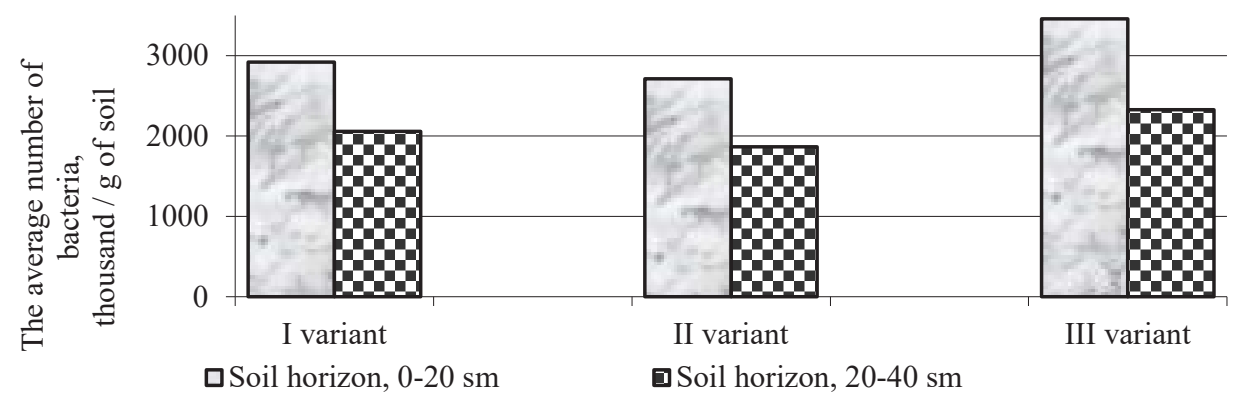

Fig. 1. The number of bacteria in the agrocenosis of Trifolium pratense depending on the method of tillage (average for 2019-2020).

One of the main objects of biogeocenosis in the soil are fungi, which are actively involved in biological processes. In particular, fungi, along with bacteria, are involved in the decomposition of plant and animal remains and promote the formation of humus.

It is established that in the conditions of the forest-steppe of Ukraine, tillage significantly affects not only the number of bacteria but also fungi (table 2).

Table 2.The number of fungi in the agrocenosis of Trifolium pratense depending on the methods of tillage, thousand /g of soil (average for the growing season).

\begin{tabular}{|c|c|c|c|c|c|c|}
\hline \multirow{2}{*}{ Method of tillage } & \multicolumn{7}{|c|}{ Soil horizon, sm } \\
\cline { 2 - 7 } & $0-20$ & $20-40$ & $0-20$ & $20-40$ & $0-20$ & $20-40$ \\
\cline { 2 - 7 } & \multicolumn{2}{|c|}{2018} & \multicolumn{2}{|c|}{2019} & \multicolumn{2}{c|}{2020} \\
\hline $\begin{array}{c}\text { Conventional } \\
\text { tillage (control) }\end{array}$ & 38,7 & 28,7 & 41,3 & 32,3 & 45,0 & 40,7 \\
\hline Chisel tillage & 36,0 & 27,0 & 35,0 & 30,3 & 42,3 & 38,3 \\
\hline Combined tillage & 41,3 & 31,7 & 43,3 & 35,3 & 46,7 & 43,0 \\
\hline
\end{tabular}

The distribution of fungi in the arable and subsoil horizons, as a rule, corresponds to the content of humus in the soil horizons: in the upper humus horizons their number is maximum, and with depth - decreases slightly. It is obvious that a large number of fungi in the upper horizons of the soil, first of all, is connected with the content of more organic substances, and with depth the quantity of organic substances decreases with simultaneous decrease and fungi.

Based on the results of the study, we found that the development of fungi in the agrocenosis of Trifolium pratense on average during the growing season was different and depended on the method of tillage. The largest number of their in the soil horizon $0-20 \mathrm{~cm}$ was in the variant of combined tillage - 41.3 thousand (2018), 43.3 thousand (2019) and 46.7 thousand / $g$ of soil (2020). The lowest rates were for chisel tillage -36.0 thousand / $\mathrm{g}$ of soil, 35.0 thousand / $g$ of soil and 42.3 thousand / $g$ of soil respectively.

Intensive development of fungi is revealed in summer months, obviously it is connected with a large number of not decomposed postharvest remains of cultures of the previous year as the greatest quantity of nutrients available to organisms accumulates in the fall with receipt of plant remains in soil. These substances are not completely decomposed by microorganisms in the fall and persist until spring. Therefore, in the spring, when there is enough moisture and undecomposed post-harvest residues, there is an increased development of bacteria and fungi.

At the same time, a smaller number of fungi was found in the subsoil horizon (20-40 $\mathrm{cm})$. This is probably due to the fact that with increasing depth, the content of undecomposed organic residues decreases and the air regime of the soil deteriorates. 
The number of fungi in the arable horizon of the soil in the variant of combined tillage averaged 2018-2020 years wasd 43.8 thousand, while for chisel and conventional tillage the figures were lower and amounted to -37.8 and 41.7 thousand / g of soil (Fig. 2).

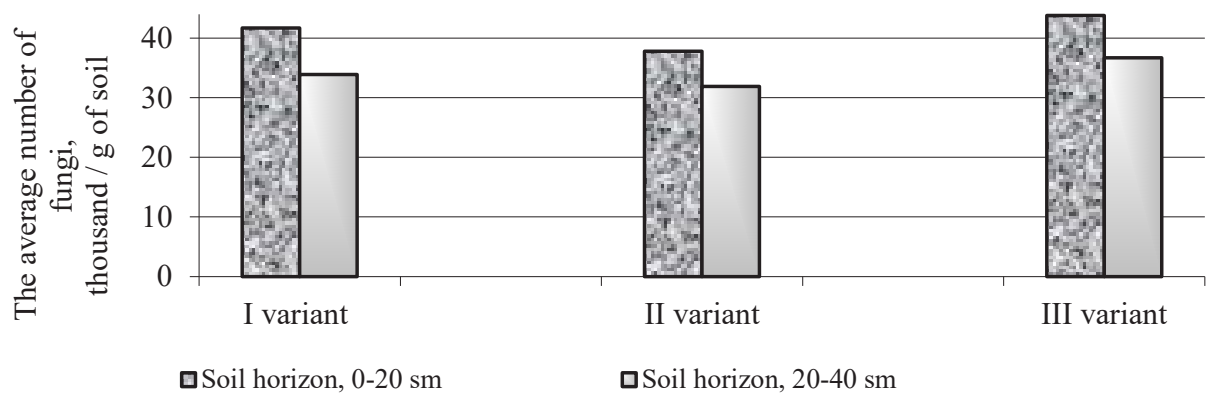

Fig. 2. The number of fungi in the agrocenosis of Trifolium pratense depending on the method of tillage (average for 2019-2020).

It is important to note that the number of fungi (as well as bacteria!) In the subsoil horizon was smaller compared to the number in the arable horizon. Assessing the condition of the soil by the number of fungi in the agrocenosis of Trifolium pratense during the growing season, we found a tendency to increase their number and viability in the case where the combined tillage was used. That is, combined tillage with plows PYA-4-40 promotes better development of fungi than conventional tillage with plows PLN-4-35 and chisel tillage with plow PCH-4,5.

In the processes of decomposition of organic matter in the soil, along with bacteria and fungi, actinomycetes also occupy a prominent place. Therefore, the study of the peculiarities of the functioning of this group of microorganisms is of great scientific and practical importance.

Actinomycetes are an intermediate group in the morphological relationship between bacteria and fungi. They are like fungi, form mycelium and like bacteria - unicellular. Actinomycetes decompose organic matter, and thus prepare the substrate for feeding higher plants.

Actinomycetes are able to influence the processes of humus formation, so their number and physiological activity are indispensable.

The dynamics of the development of actinomycetes in the soil of the Trifolium pratense agrocenosis changed under the influence of the tillage method (Table 3).

Table 3. The number of actinomycetes in the agrocenosis of Trifolium pratense depending on the method of tillage, thousand / $\mathrm{g}$ of soil (average for the growing season).

\begin{tabular}{|c|c|c|c|c|c|c|}
\hline \multirow{2}{*}{ Method of tillage } & \multicolumn{7}{|c|}{ Soil horizon, sm } \\
\cline { 2 - 7 } & $0-20$ & $20-40$ & $0-20$ & $20-40$ & $0-20$ & $20-40$ \\
\cline { 2 - 7 } & \multicolumn{2}{|c|}{2018} & \multicolumn{2}{|c|}{2019} & \multicolumn{2}{|c|}{2020} \\
\hline $\begin{array}{c}\text { Conventional } \\
\text { tillage (control) }\end{array}$ & 1519,3 & 1298,0 & 1508,7 & 1334,7 & 1544,7 & 1379,7 \\
\hline Chisel tillage & 1439,0 & 1207,0 & 1473,0 & 1238,0 & 1516,0 & 1309,3 \\
\hline Combined tillage & 1579,7 & 1386,0 & 1606,0 & 1372,7 & 1674,0 & 1473,7 \\
\hline
\end{tabular}

It was found that on the experimental dark gray podzolic light loam soil actinomycetes are much smaller amount than bacteria. The unequal number of them on average over the years of research indicates that the number of microorganisms in the soil depends significantly on the meteorological conditions of the year. The lowest number of actinomycetes (1207.0, 1238.0 and 1309.3 thousand / $\mathrm{g}$ of soil) was in the horizon of 20-40 
cm during chisel tillage compared to the combined (1386.0, 1372.7 and 1473.7 thousand / $\mathrm{g}$ of soil) and conventional tillage (1298.0, 1334.7, and 1379.7 thousand / g of soil).

The maximum number of actinomycetes in the spring and autumn is connected with enrichment of soil with the organic remains. Two maxima of actinomycete development activity can obviously be explained by the seasonality of the accumulation of organic residues. in the spring there are many readily available organic substances, the raised temperature of soil promotes the strengthened development of actinomycetes.

In late summer, the amount of readily available organic matter decreases, while the number of actinomycetes decreases. The new influx of organic matter due to the death of the root mass of plants in late summer, leads to an increase in the number of actinomycetes that are involved in the decomposition of plant residues, even with smaller reserves of moisture.

It was also found that the arable soil horizon differed from the subsoil horizon by a larger number of actinomycetes.

Chisel tillage with a plow PCH-4.5 leads to a decrease in the number of actinomycetes in the soil during the growing season. The maximum number of actinomycetes was obtained by combined tillage with the PYA-4-40 plow. In the arable horizon of the soil in the variant of combined tillage for the years of research the number of actinomycetes averaged 1620,0 thousand / $\mathrm{g}$ of soil, while for chisel and conventional tillage rates were lower and amounted to $-1476,0$ and 1524,0 thousand / $\mathrm{g}$ of soil (Fig. 3).

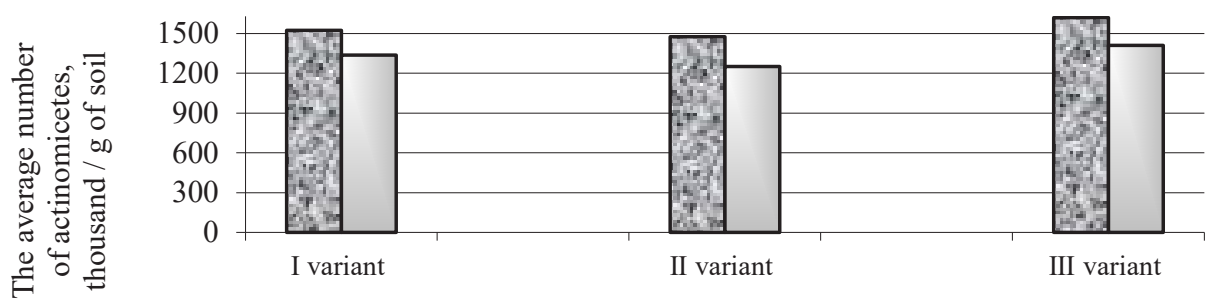

口Soil horizon, 0-20 sm ㄴ Soil horizon, 20-40 sm

Fig. 3. The number of actinomycetes in the agrocenosis of Trifolium pratense depending on the method of tillage (average for 2019-2020).

An integral indicator of economic evaluation of tillage is the yield of the grown crop, which is derived from the sum of factors under which the formation of the crop. On average, in 2018-2020, the highest yield of hay was obtained with the combined tillage (124.5 c / ha), with chisel and conventional: $106.5 \mathrm{c} /$ ha and $115 \mathrm{c} / \mathrm{ha}$, respectively, due to the change microbiological activity of the soil (table 4).

Table 4. Yield of Trifolium pratense depending on the method of tillage (sum of two slopes together for two slopes), $\mathrm{c} / \mathrm{ha}$.

\begin{tabular}{|c|c|c|c|c|c|c|}
\hline \multirow[b]{2}{*}{ Method of tillage } & \multicolumn{3}{|c|}{ Year } & \multirow{2}{*}{$\begin{array}{l}\text { The average } \\
\text { for } 2018 \text { - } \\
2020\end{array}$} & \multicolumn{2}{|c|}{ \pm to control } \\
\hline & 2018 & 2019 & 2020 & & $\mathrm{c} / \mathrm{ha}$ & $\%$ \\
\hline $\begin{array}{l}\text { Conventional tillage } \\
\text { (control) }\end{array}$ & 126,9 & 101,8 & 116,3 & 115 & - & \\
\hline Chisel tillage & 118,1 & 94,2 & 107,1 & 106,5 & $-8,5$ & 7,4 \\
\hline Combined tillage & 141,5 & 107,9 & 124,1 & 124,5 & $+9,5$ & 8,3 \\
\hline $\mathrm{LSD}_{05}$ & 7,0 & 5,2 & 6,1 & & & \\
\hline
\end{tabular}




\section{Discussion and conclusions}

Perennial grasses, especially legumes, not only provide the livestock industry with highprotein feed, but also play an important role in the biologization of agriculture, as they affect soil fertility and the state of the environment. Trifolium pratense is one of the main perennial grasses in Ukraine and an important source of fodder vegetable protein.

The main tillage has a significant impact on the biological activity of the soil, the number of microbiota and the yield of Trifolium pratense hay. The combined tillage (plowing with a plow PYA-4-40) creates the most favorable environment for microorganisms: bacterial microbiota (3458,3 thousand /g. soil), fungi (43.8 thousand /g. soil) and actinomycetes (1620,0 thousand /g of soil).

It is established that on average in 2018-2020 the highest yield of hay was obtained by the combined method of basic tillage $-124.5 \mathrm{c} /$ ha.

\section{References}

1. S.V. Begey, I.A. Shuvar, Ecological agriculture, 429 (2020).

2. V.V. Snitynsky, A.Y. Gabriel, O.M. Germanovich and oth, Silskohospodarska mikrobiolohiia 19, 47-51 (2014)

3. O.S. Demyanyuk, O.V. Sherstoboeva, E.D. Tkach, Microbiolohichnyi Journal 6, 94$108(2018)$

4. O.S. Demyanyuk, O.V. Sherstoboeva, V.V. Chaikovska, O.A. Demidov, Zbalansovane pryrodokorystuvannya 2, 146-151 (2016)

5. B.A. Dospekhov, Field experiment technique, 351(1985)

6. V.A. Dumova, N.V. Patyka, V.Yu. Kruglov and oth., Mikrobiolohiya i biotekhnolohiya 6, 60-65 (2009)

7. V.V. Volkohon, O.V. Nadkernicna, L.M. Tokmakova and oth., Experimental soil microbiology, 464 (2010)

8. L.I. Fedak, Agroecolohichnyi journal 3, 93-94 (2009)

9. V.P. Gordienko, S.M. Sychevsky, Nauchnye Trudy Krymskogo GAU 66, 60-65 (2000)

10. T.R. Gray, S.T. Williams, Soil microorganisms, 550 (London, 1987)

11. C.S. Harwood, E.P. Greenberg, Science 286, 1096 (1999)

12. A.C. Kennedy, V.L. Gewin, Soil Sci. 9, 607-617 (1997)

13. S.Ya. Kots, N.V. Patika, V.F. Patika, Kormy i kormovyrobnytstvo, 62 228-234 (2008)

14. L.M. Krasyuk, Zbirnyk naukovykh prats' NNTS «Instytut zemlerobstva NAAN» 1-2, 3-9 (2011)

15. D.G. Zvyagintsev, I.V. Aseeva, N.P. Babiev and others, Methods of soil microbiology and biochemistry, 224 (Moscow State University, 1980)

16. E.N. Mishustin, A.N. Petrova, Microbiologiia 3, 479-482 (1963)

17. D.I. Nikitin, Soil microbiology, 318 (1979)

18. J.M. Oades, Geoderma 56, 377- 400 (1993)

19. N.V. Patyka, Yu.V. Kruglov, A.M. Berdnikov, V.F. Patyka, Microbiolohichnyi journal 1, 58-69 (2008)

20. A. Piterson, D. Greman, International Symposium "Structure and Function of Soil Microbiota", 235-236 (2005)

21. L.I. Prus, Karantyn i zakhyst roslyn 7 (238), 4-8 (2016) 
22. T.V. Radko, V.G. Radko, Zemlerobstvo 84, 69-74 (2012)

23. I.P. Shevchenko, Yu.O. Drach, S.V. Yatsenko, Visnyk ahrarnoyi nauky 10, 12-15 (2006)

24. I.A. Shuvar, Scientific bases of crop rotations of intensive-ecological agriculture, 223 (1998)

25. I.A. Shuvar, H. Korpita, Biologization of potato growing technology in the western forest steppe. Innovatsiyni tekhnolohiyi v roslynnytstvi III Vseukrayins'ka naukova internet-konferentsiya (15.07.2020) Kamyanets'-Podil's'kyy, 153-156 (2020)

26. I.A. Shuvar, H.M. Korpita, Peredhirne ta hirs'ke zemlerobstvo i tvarynnytstvo 60, $162-$ 169 (2016)

27. I.A. Shuvar, H.M. Korpita, Productivity of agrocenosis of spring barley under conditions of modern agriculture in the context of global climate change. Mizhnarodna naukova internet-konferentsiya "Suchasnyy stan nauky $v$ sil's'komu hospodarstvi ta pryrodokorystuvanni: teoriya i praktyka" (20.11. 2019) Ternopil, 241-243 (2019)

28. I.A. Shuvar, B.I. Shuvar, Organic farming and its prospects 9, 18-20 (2007)

29. S.P. Tanchyk, V.Yu. Yamkovy, Naukovyy visnyk NUBiP Ukrayiny 145, 45-49 (2010)

30. Ya.P. Tsvey, L.O. Hogol, Tsukrovi buryaky 5, 4-5 (2005)

31. A.A. Tsyuk, V.I. Kirilyuk, Microbiolohichnyi Journal 4, 104-111 (2016)

32. V.V. Volkohon, O.M. Berdnikov, L.M. Tokmakova, I.V. Larchenko, Visnyk ahrarnoyi nauky 2, 5-10 (2017) 